\title{
Effects of partial replacement of barley with sugar beet pulp on pre- and post-partum performance of Zel ewes
}

\author{
M. Ghadami Kohestani ${ }^{1}$, A. Teimouri Yansari ${ }^{2 \#} \&$ M. Rezaei $^{1}$ \\ ${ }^{1}$ Department of Animal Science, Animal Science and Aquaculture Faculty, Agricultural and Natural Resource \\ University, Sari, Mazandaran, Iran \\ ${ }^{2}$ Department of Animal Science, Animal Science and Aquaculture Faculty, Agricultural and Natural Resource \\ University, Sari, Mazandaran, Iran and Department of Animal Science, Educational Centre of Tajan, GhaemShahar, \\ Mazandaran, Iran
}

Copyright resides with the authors in terms of the Creative Commons Attribution 2.5 South African Licence.

See: http://creativecommons.org/licenses/by/2.5/za

Condition of use: The user may copy, distribute, transmit and adapt the work, but must recognise the authors and the South African Journal of Animal Science.

\begin{abstract}
Sixteen Zel ewes $(\mathrm{BW}=37 \pm 3.10 \mathrm{~kg})$ were used in a completely randomized design to determine the effects of partial replacement of barley grain with beet pulp (BP), during late pregnancy and early lactation, on litter weight, lamb's daily gain, milk yield and milk composition. Dietary treatments were initiated approximately three weeks prior to expected lambing dates, and continued for three weeks post-partum. Treatments consisted of 1) a basal diet $+330 \mathrm{~g} / \mathrm{kg}$ of barley grain (BBG), and 2) a basal diet $+195 \mathrm{~g} / \mathrm{kg}$ of barley $+135 \mathrm{~g} / \mathrm{kg} \mathrm{BP}(\mathrm{BBP})$. The basal diet contained 444, 117, 101 and $8 \mathrm{~g} / \mathrm{kg}$ of wheat straw, wheat bran, canola meal and mineral-vitamin mix supplement, respectively. Both diets were offered as a total mixed ration twice daily. Partial replacement of BP increased feed intake. Diets did not affect milk compositions but feeding BBP increased milk yield (1084 vs. $737 \mathrm{~g} / \mathrm{d})$, litter weight (3453 vs. $2735 \mathrm{~g})$ and lambs' daily gain $(218 v s .156 \mathrm{~g} / \mathrm{d})$. The lambs' live weight at $14 \mathrm{~d}(5992 v s .4749 \mathrm{~g})$ and $21 \mathrm{~d}(7553$ vs. $5854 \mathrm{~g})$ was affected by maternal nutrition and a higher BBP. The results of this study indicate that late gestation and early lactation ewes can be supplemented with BP without detrimental effects on milk production or milk composition, and feeding ewes with BP during this period resulted in increased litter weight and growth of lambs.
\end{abstract}

Keywords: Dietary carbohydrate source, sheep, lambs, non-forage fibre, non-fibre carbohydrate

${ }^{\#}$ Corresponding author: astymori@yahoo.com

\section{Introduction}

Transition nutrition could have a tremendous impact on animal performance and viability of the neonatal animal. An exponential foetal growth pattern places the greatest nutritional burden of pregnancy on the pregnant dam with more than $60 \%$ of the foetal growth occurring in the final month of gestation. Therefore, the nutrient requirements of the ewe increase due to the rapid growth rate of the foetus. Late gestation diets should be formulated to at least meet the minimum requirements but, adjusted to an appropriate intake level and forage quality. Incidentally, maternal strategies for accommodating the substantial requirements of the conceptus include increased hepatic gluconeogenesis (Ingvartsen \& Andersen, 2000), increased fatty acid mobilization from adipose tissue (Overton \& Waldron, 2004; Smith et al., 2005; Nafikov et al., 2006), decreased peripheral tissue glucose utilization, and possibly, an increased amino acid mobilization from muscle (Bell, 1995; Ingvartsen \& Andersen, 2000). In addition, during this period, reduced intake (Coffey et al., 1989) and inadequate glucose synthesis may predispose the animal to health disorders and limit milk production (Karcher et al., 2007). Therefore, the energy density of the diet should be increased prior to lambing. Grain is often substituted for forage in diets in an effort to increase energy intake. However, the starch in grain inhibits fibre digestion by depressing rumen $\mathrm{pH}$ or through competition with starch as a substrate (Van Soest, 1994). Therefore, balancing the diets at the appropriate 
pre- and post-partum levels and types of dietary carbohydrates is a major concern in ration formulation and is necessary to maximize production while ensuring the health of the animals.

A potential method of varying non-fibrous carbohydrate (NFC) content of the pre-partum diet without confounding it with energy or fat content, would be to include a non-forage fibre source (NFFS) such as sugar beet pulp (BP) (Smith et al., 2005). Non-forage fibre sources have higher available energy values than most forages (Firkins, 1997), higher fibre digestibility (Cunningham et al., 1993) and molar proportions of acetate (Mansfield et al., 1994) when replacing cereal grains, and have a lower NFC content than most starchy cereal grains (NRC, 2001). Beet pulp has a similar range of NDF content as forages but its particle size is generally smaller than that of forages (Allen, 2000) and is unique in its high concentration of neutral detergent soluble fibre, especially pectic substances (Voelker \& Allen, 2003; Dann et al., 2007; Murray et al., 2008). The NDF in BP can be digested more quickly than forage NDF (Dann et al., 2007). However, few studies (O'Doherty \& Crosby, 1996; O'Doherty et al., 1997) have evaluated the responses to various NFFS substituted for grain and the effects of NFC content of the pre- and post-partum diet independent of dietary energy in ewes. Therefore, this study was conducted to determine the effects of the partial replacement of barley grain with BP, during late pregnancy and early lactation, on litter weight, live weight gain of lambs, feed intake, milk yield and milk compositions in ewes.

\section{Material and Methods}

The study was carried out at the Ruminant Research Centre of Sari Agricultural and Natural Resources University, Sari, Iran. The experiment was done in accordance with the National Health and Medical Research Council of Australia guidelines. The feeding trial continued for six weeks in which the feed intake and live weight changes were measured. Sixteen Zel ewes of known mating date $(\mathrm{BW}=37.0 \pm 3.10 \mathrm{~kg}$ (standard deviation)), were selected for the study (the length of the mating period was one week), and weighed and divided into two different weight groups, which represented the replications of the experiment using a completely randomized design. All the ewes were randomly allocated to the experimental feeds to evaluate the effect of partial replacement of barley grain with BP on animal performance during pre- and post-partum. The ewes were, on average, three years old, clinically healthy and in good physical condition. Ewes were randomly allocated to one of two treatments by the order in which they lambed. Dietary treatments were initiated approximately three weeks prior to the expected lambing dates and continued for three weeks post-partum. Treatments consisted of 1) a basal diet $+330.8 \mathrm{~g}$ of barley grain $/ \mathrm{kg}, 2$ ) a basal diet $+195.5 \mathrm{~g}$ of barley grain $/ \mathrm{kg}+135.3 \mathrm{~g} \mathrm{BP} / \mathrm{kg}$. The basal diet contained 443.6, 116.5, 101.5 and $7.6 \mathrm{~g} / \mathrm{kg}$ of wheat straw, wheat bran, canola meal and a mineral-vitamin mix supplement, respectively (Table 1). The nutrient composition of the diets is presented in Table 1. Both diets were formulated using the Sheep Cornell Net Carbohydrate and Protein System (Sheep CNCPS, 2007) to meet the requirements for dry and lactating ewes and offered as a total mixed ration. Ewes were housed in individual pens. Feed was offered twice a day at 07:00 and 17:00, at a level of 10\% above ad libitum intake, during the experiment. Refusals were collected and weighed every morning to estimate feed intake. Feed and water were withheld overnight. Samples of refusals, collected from individual ewes every day, were pooled during the entire experimental period and subsampled for analysis. The feed was sampled regularly and analyzed for DM, crude protein (CP), ether extract (EE), ash at $605{ }^{\circ} \mathrm{C}$ (AOAC, 2002), neutral detergent fibre (NDF) and acid detergent fibre (ADF) (Van Soest et al., 1991). Non-fibrous carbohydrate (NFC) was calculated as:

$\mathrm{NFC}=100-(\mathrm{CP} \%+\mathrm{NDF} \%+\mathrm{Ash} \%+\mathrm{EE} \%)(\mathrm{NRC}, 2001)$.

The ewes were weighed on the first day of the experiment and subsequently at weekly intervals before being offered the morning feed on the same day of the week. The lambs were penned individually on slatted floors. All ewes lambed in their pens and remained there with their lambs until $24 \mathrm{~h}$ post-partum. The lambs were then separated from the ewes and allowed 15 min access to their dams daily at 7:00, 12:00, 17:00 and 22:00. Lambs were weighed at birth and daily during the three weeks after birth. The lambs' daily gain (g/day) was calculated by the weight difference of two consecutive days. The average daily body weight gain (ADWG), during the experimental period, was calculated by regressing body weight of lamb on number of days of feeding.

Milk samples were manually collected daily at 07:00. Samples of milk were immediately frozen and maintained at $-20{ }^{\circ} \mathrm{C}$ until used for analysis of fat, protein, lactose, total solids (TS) (protein + fat + lactose), and solid not-fat (SNF) (protein + lactose), by using a CombiFoss 5000 instrument (Foss Electric, Hillerød, Denmark). Milk yields were measured during the three weeks of lactation using the lamb-suckling method 
(Benson et al., 1999). The lambs were weighed immediately before and after being suckled. The daily milk yields were calculated by the summative weight differences of the lambs. Milk fat and protein yield was estimated by multiplying milk yield by milk fat or protein percentage.

The blood samples were taken from the jugular vein into vacutainers. The serum was separated by centrifugation at $750 \times \mathrm{g}$ for $15 \mathrm{~min}$ and stored at $-20{ }^{\circ} \mathrm{C}$ until used. The concentrations of glucose, cholesterol, triglyceride and HDL-cholestrol were measured using appropriate commercial laboratory kits (Zistshimi and Parsazmoon). VLDL-cholesterol was estimated as one fifth of the concentration of triglycerides (Friedewald et al., 1972).

The experimental design consisted of a completely randomized design with repeated measurements on the animals. An analysis of variance was conducted using the SAS General Linear Models procedure (SAS, 2002) using the model:

$$
\mathrm{Y}_{\mathrm{ijk}}=\mu+\alpha_{\mathrm{i}}+\beta_{\mathrm{ij}}+\mathrm{t}_{\mathrm{k}}+\mathrm{e}_{\mathrm{ijk}}
$$

where $Y_{\mathrm{ijk}}$ is the dependent variable, $\mu$ is the overall mean, $\alpha_{\mathrm{i}}$ is the random effect of diets ( $\mathrm{i}=1$ and 2), $\beta_{\mathrm{ij}}$ is the random effect of animal $j$ in treatment group $i, t_{k}$ is a fixed effect of time $k$, and $e_{i j k}$ is the random error at time $\mathrm{k}$ on animal $\mathrm{j}$ in treatment $\mathrm{i}$. Lamb sex was not a significant source of variation for any parameter and was omitted from the model. Means were separated using the LS means procedure with an alpha level of 0.05 (treatment means were evaluated with the PDIFF option of SAS).

\section{Results}

The ingredients and chemical composition of the rations that were fed to the ewes, are presented in Table 1. The DM, CP, EE and ash contents of the two diets were similar. However, the partial replacement of barley grain with BP decreased NFC content and increased NDF content of the diet in treatment 2 $(P<0.05)$.

Table 1 Ingredient and chemical composition of the experimental diets

\begin{tabular}{lllll}
\hline \multirow{2}{*}{ Ingredient } & \multicolumn{2}{c}{ Diets } & \\
\cline { 2 - 3 } & 1 & 2 & & \\
\hline Ingredients, g/kg DM & & & & \\
$\quad$ Barley & 330.8 & 195.5 & - & - \\
$\quad$ Sugar beet pulp & 0 & 135.3 & - & - \\
$\quad$ Canola meal & 101.5 & 101.5 & - & - \\
$\quad$ Wheat bran & 116.5 & 116.5 & - & - \\
$\quad$ Wheat straw & 443.6 & 443.6 & - & - \\
$\quad$ Mineral-vitamin premix & 7.6 & 7.6 & - & - \\
Chemical compositions, g/kg DM & & & & \\
$\quad$ Dry matter & 890.4 & 894.4 & 5.20 & 0.72 \\
$\quad$ Crude protein & 130.3 & 126.0 & 2.82 & 0.52 \\
Neutral detergent fibre & $496.0^{\mathrm{b}}$ & $523.0^{\mathrm{a}}$ & 3.41 & 0.02 \\
Non-fibrous carbohydrate & $284.7^{\mathrm{a}}$ & $259.0^{\mathrm{b}}$ & 3.76 & 0.02 \\
Ether extract & 24.2 & 23.0 & 0.64 & 0.52 \\
Ash & 64.8 & 69.0 & 1.78 & 0.34 \\
& & & & \\
\hline
\end{tabular}

${ }^{\mathrm{a}, \mathrm{b}}$ Means within a row with different subscripts differ $(P<0.05)$.

Diet $1-$ Basal + barley grain; Diet $2-$ Barley grain partially replaced by beet pulp.

The DM intake was significantly different between treatments, at all times over the pre to post-partum periods, and the ewes on Diet 2 had a higher DMI than those on Diet 1 (Table 2). 
Table 2 Body weight, body weight changes and dry matter (DM) intake of ewes receiving a basal feed + barley grain (Diet 1) and Diet 2, in which barley grain was partially replaced by sugar beet pulp

\begin{tabular}{lcccc}
\hline \multirow{2}{*}{ Item } & \multicolumn{2}{c}{ Diet $^{1}$} & & \\
\cline { 2 - 3 } & 1 & 2 & & \\
& & & & \\
\hline Body weight, kg & & & & \\
Three weeks before lambing & 37.0 & 36.9 & 1.02 & 0.12 \\
One day after lambing & 32.0 & 33.2 & 1.78 & 0.08 \\
Three weeks after lambing & 31.0 & 33.8 & 1.00 & 0.09 \\
$\quad$ Total body weight changes, kg & $-5.97^{\mathrm{b}}$ & $-3.07^{\mathrm{a}}$ & 0.62 & $<0.01$ \\
DM intake, kg & & & & \\
Three weeks before lambing & $1.31^{\mathrm{b}}$ & $1.40^{\mathrm{a}}$ & 0.008 & $<0.01$ \\
Two weeks before lambing & $1.21^{\mathrm{b}}$ & $1.32^{\mathrm{a}}$ & 0.006 & $<0.01$ \\
One week before lambing & $1.14^{\mathrm{b}}$ & $1.21^{\mathrm{a}}$ & 0.012 & $<0.01$ \\
Day of lambing & $1.01^{\mathrm{b}}$ & $1.14^{\mathrm{a}}$ & 0.014 & $<0.01$ \\
One week after lambing & $1.18^{\mathrm{b}}$ & $1.38^{\mathrm{a}}$ & 0.009 & $<0.01$ \\
Two weeks after lambing & $1.29^{\mathrm{b}}$ & $1.47^{\mathrm{a}}$ & 0.014 & $<0.01$ \\
Three weeks after lambing & $1.39^{\mathrm{b}}$ & $1.64^{\mathrm{a}}$ & 0.011 & $<0.01$ \\
\hline
\end{tabular}

${ }^{\mathrm{a}, \mathrm{b}}$ Means within a row with different subscripts differ $(P<0.05)$.

${ }^{1}$ Least square means.

Table 3 Milk yield and milk composition of ewes receiving a basal diet + barley grain (Diet 1 ) and Diet 2 , in which sugar beet pulp partially replaced barley grain

\begin{tabular}{lcccc}
\hline \multirow{2}{*}{ Item } & \multicolumn{2}{c}{ Diet $^{1}$} & \multirow{2}{*}{ SEM } & $P$-value \\
\cline { 2 - 3 } & 1 & 2 & & \\
\hline Milk, g/d & $737.5^{\mathrm{b}}$ & $1084.1^{\mathrm{a}}$ & 51.1 & $<0.01$ \\
Milk composition, g/kg & & & & \\
$\quad$ Lactose & 51.8 & 52.1 & 1.50 & 0.91 \\
$\quad$ Fat & 53.7 & 62.2 & 5.00 & 0.23 \\
$\quad$ Protein & 59.2 & 61.9 & 2.80 & 0.47 \\
$\quad$ Total solids & 164.7 & 176.1 & 6.10 & 0.19 \\
$\quad$ Solids non-fat & 111.0 & 114.0 & 2.20 & 0.33 \\
Milk composition, g/day & & & & \\
$\quad$ Lactose & $38.4^{\mathrm{b}}$ & $58.4^{\mathrm{a}}$ & 3.20 & $<0.01$ \\
$\quad$ Fat & $39.4^{\mathrm{b}}$ & $68.6^{\mathrm{a}}$ & 6.50 & $<0.01$ \\
$\quad$ Protein & $43.7^{\mathrm{b}}$ & $69.3^{\mathrm{a}}$ & 5.00 & $<0.01$ \\
$\quad$ Total solids & $121.5^{\mathrm{b}}$ & $190.9^{\mathrm{a}}$ & 4.70 & $<0.01$ \\
$\quad$ Solids non-fat & $81.9^{\mathrm{b}}$ & $123.6^{\mathrm{a}}$ & 5.30 & $<0.01$ \\
\hline a,b & & & \\
\hline
\end{tabular}

The body weights of ewes were similar at three weeks before lambing, at lambing time and three weeks after lambing (Table 2). Total body weight changes were significantly higher in treatment 1 than in treatment 2 . Ewes fed on a ration containing the basal diet plus barley lasted longer than ewes fed the ration 
containing the basal diet plus barley and BP, and were on a negative energy balance and lost more body weight (5.97 vs. $3.07 \mathrm{~kg})$.

The use of BP in the ration significantly increased the milk yield. Ewes fed on treatment 2 produced $47 \%$ more milk than ewes fed on treatment 1 . However, the milk composition was not affected by treatment, but yields of the different milk components were significantly higher in treatment 2 than in treatment 1 (Table 3).

The birth weight of lambs, their live weight and daily live weight gain are shown in Table 4. Birth weight was greater for ewes on Diet 2 than those on Diet 1 . No significant difference was found in lambs' live weight at $7 \mathrm{~d}$, but lamb weight at $14 \mathrm{~d}(5992.4 v s .4748 .8 \pm 42.2 \mathrm{~g})$ and $21 \mathrm{~d}(7552.7 v s .5854 .5 \pm 50.3 \mathrm{~g})$ was significantly higher for ewes on treatment 2 than on treatment 1 . In addition, the average daily gain of lambs was significantly lower on treatment 1 than on treatment 2 (Table 4).

Table 4 Birth weights, live weights and daily live weight gains of lambs from ewes receiving a basal feed + barley grain (Diet 1 ) and Diet 2, in which barley grain was partially replaced by sugar beet pulp

\begin{tabular}{|c|c|c|c|c|}
\hline \multirow{2}{*}{ Item } & \multicolumn{2}{|c|}{$\operatorname{Diet}^{1}$} & \multirow{2}{*}{ SEM } & \multirow{2}{*}{$P$-value } \\
\hline & 1 & 2 & & \\
\hline \multicolumn{5}{|c|}{ Lambs' weight, g } \\
\hline Birth & $2735^{\mathrm{b}}$ & $3453^{\mathrm{a}}$ & 16.20 & $<0.01$ \\
\hline $7 \mathrm{~d}$ & 3779 & 4021 & 20.85 & 0.32 \\
\hline $14 \mathrm{~d}$ & $4749^{b}$ & $5992^{\mathrm{a}}$ & 42.16 & $<0.01$ \\
\hline $21 \mathrm{~d}$ & $5855^{\mathrm{b}}$ & $7553^{\mathrm{a}}$ & 50.29 & $<0.01$ \\
\hline Daily gain, $\mathrm{g} / \mathrm{d}$ & $156^{\mathrm{b}}$ & $218^{\mathrm{a}}$ & 2.72 & $<0.01$ \\
\hline
\end{tabular}

${ }^{\mathrm{a}, \mathrm{b}}$ Means within a row with different subscripts differ $(P<0.05)$.

${ }^{1}$ Least square means.

Table 5 Blood metabolites of ewes receiving a basal feed + barley grain (Diet 1) and Diet 2, in which barley grain was partially replaced by sugar beet pulp

\begin{tabular}{|c|c|c|c|c|}
\hline \multirow{2}{*}{ Item } & \multicolumn{2}{|c|}{$\operatorname{Diet}^{1}$} & \multirow{2}{*}{ SEM } & \multirow{2}{*}{$P$-value } \\
\hline & 1 & 2 & & \\
\hline Glucose, $\mathrm{mg} / \mathrm{dL}$ & 41.2 & 44.7 & 0.93 & 0.38 \\
\hline Cholesterol, mg/dL & 30.8 & 32.9 & 0.95 & 0.59 \\
\hline Triglycerides, mg/dL & $32.0^{\mathrm{a}}$ & $21.2^{\mathrm{b}}$ & 0.81 & 0.02 \\
\hline HDL-cholesterol, mg/dL & $35.3^{\mathrm{a}}$ & $25.6^{\mathrm{b}}$ & 0.03 & $<0.01$ \\
\hline VLDL-cholesterol, mg/dL & $7.6^{\mathrm{a}}$ & $5.7^{\mathrm{b}}$ & 0.16 & 0.02 \\
\hline
\end{tabular}

\footnotetext{
${ }^{\mathrm{a}, \mathrm{b}}$ Means within a row with different subscripts differ $(P<0.05)$.

${ }^{1}$ Least square means.

$\mathrm{HDL}=$ high density lipoprotein $; \mathrm{VLDL}=$ very low density lipoprotein.
}

The concentrations of glucose and cholesterol were similar between treatments, but concentrations of triglycerides (21.22 vs. $32.01 \mathrm{mg} / \mathrm{dL})$, HDL-cholesterol (25.56 vs. $35.30 \mathrm{mg} / \mathrm{dL})$ and VLDL-cholesterol (2.09 vs. $3.32 \mathrm{mg} / \mathrm{dL})$ were lower $(2.09 \mathrm{vs.} 3.32 \mathrm{mg} / \mathrm{dL})$ in treatment 2 than in treatment 1 . 


\section{Discussion}

Based on current NRC recommendations, late gestation diets for sheep and goats should contain between 130 and $150 \mathrm{~g} \mathrm{CP} / \mathrm{kg} \mathrm{DM}$ and be fortified with minerals and vitamins. Good quality forage $(<420$ $\mathrm{g} / \mathrm{kg}$ NDF) with 200 to $600 \mathrm{~g}$ of a concentrate should be an adequate blend to meet the energy needs of the animal. However, in the current experiment, the rations had an NDF greater than the optimum level. The BP, decreased NFC content and increased NDF content of Diet 2 was used because BP contains more than $400 \mathrm{~g}$ $\mathrm{NDF} / \mathrm{kg} \mathrm{DM}$ and is unique in its high concentration of neutral-detergent soluble fibre, especially pectic substances (about $250 \mathrm{~g} / \mathrm{kg}$ of DM). Therefore, BP is often used to reduce the content of NFC in diets when it is replaced with grains or forages, but interactions between the feeding of BP and dietary forage fibre or grains are critical. Barley had $184 \pm 21.20,135 \pm 12.10$ and $847 \pm 33.20 \mathrm{~g} / \mathrm{kg}$ NDF, CP and TDN, respectively. In addition, the BP had $446 \pm 56.50,104 \pm 14.50$ and $847 \pm 65.30 \mathrm{~g} / \mathrm{kg} \mathrm{NDF}, \mathrm{CP}$ and TDN, respectively. Barley is used primarily as an energy and protein source in sheep diets. The energy content of barley is slightly lower than the energy value of other grains, because of its higher fibre concentration and its low digestibility. The starch in barley ferments rapidly. The CP concentration of barley is similar to other major feed grains. The protein degradability of barley is similar to other small grains at approximately 20 to $30 \%$ undegraded intake protein. Digestible DM and OM, and the DE of BP were above $80 \%$. The OM digestibility of BP ranged from 85 to $89 \%$ (Jarrige, 1989; Mara, 1999). Digestible NDF and ADF were high, between 80 and $90 \%$, indicating that cell-wall carbohydrates in BP are readily fermented by microbial activity in the gut. Beet pulp has a higher energy value than most forage fibres (Firkins, 1997), a higher fibre digestibility (Cunningham et al., 1993) and a lower NFC content than most starchy cereal grains (NRC, 2001). Increasing the intake of fermentable carbohydrate increases pre- and post-partum energy intake (Grummer, 1995) and reduces the dietary NDF concentration by decreasing the forage-to-concentrate ratio, thus reducing the filling effect of the feed (Allen, 2000). However, increasing dietary starch can also negatively affect feed intake and milk production (Voelker \& Allen, 2003) by lowering the rumen $\mathrm{pH}$, which is known to have negative effects on cellulolytic bacteria (Sveinbjornsson et al., 2006).

At all times during pre- to post-partum the DM intake in Diet 2 was higher than in Diet 1 . The improved feed utilization of the sheep consuming BP, was likely due to the higher levels of energy in BP compared to barley in the rations. Beet pulp has slightly higher energy values because of two factors: firstly, the energy in the fibre of the BP is greater than the combined fibre and starch in barley and secondly, the fibre in BP has a complementary effect on energy digestion in the total diet. This is due to the slower rate of digestion of the fibre in BP, in contrast to the faster breakdown of starch in barley, which increases rumen acidity that adversely affects ruminal fibre digestion. The responses of DMI to various non-forage fibre sources, substituted for grain, are not consistent (Allen, 2000). Swain \& Armentano (1994) reported no effect on DMI. Substituting BP at $16 \%$ of DM into a high-corn diet (Clark \& Armentano, 1997) increased feed intake in cows by only $0.4 \mathrm{~kg} / \mathrm{d}$, while replacing half of the corn with BP in a higher-forage diet (Mansfield et al., 1994) reduced intake by $1.3 \mathrm{~kg} / \mathrm{d}$. The results of this study indicate that adding BP to early lactation diets might reduce the negative effects of increased starch fermentation without increasing the filling effect of the feed and increase the milk yield without detrimental effects on milk compositions.

However, few studies (O'Doherty \& Crosby, 1996; O'Doherty et al., 1997) have evaluated the responses to BP substituted for grain and the effects of NFC content of the pre-partum diet independent of dietary energy in late pregnant ewes. Replacing part of the grain in the ration the BP serves to minimize ruminal acidosis and related health problems by reducing the fermentation rate per unit of time in the rumen (Grant, 1997). Typical NDF digestion rates for forages are about 4 to $5 \% / \mathrm{h}$, while those for starch are 10 to $35 \% / \mathrm{h}$ (Van Soest, 1994). Consequently, the dilution of NFC with NDF from BP results in slower rates of fermentation, reduced acid load in the rumen, and increased the ability to feed a highly digestible diet while reducing the risk of ruminal acidosis. However, the effects of BP, when substituted with different feed sources in a total mixed ration (TMR), depend on chemical composition, types and physical characteristics. It is not known to what extent varying the concentration, types, and combinations of NFC may alter intake, digestibility, ruminal passage rate and metabolites, chewing activity and lactation performance. Feed intake can be affected by innumerable variables, such as ruminal fill, meal patterns, metabolic fuels and ruminal patterns of fermentation and $\mathrm{pH}$ (Voelker \& Allen, 2003). The NDF content of forages or total diet has been shown to be a primary mediator of intake in ruminant. In addition, more NFC in the diet leads to greater ruminal propionate concentrations (Minor et al., 1998). Ruminants fed on high starch diets, that have an increased metabolizable energy (ME), tend to have an increased microbial amino acid supply (Oba \& Allen, 
2003), but are more predisposed to suffering from ruminal acidosis (Lanzas et al., 2007). Propionate, produced by fermentation in the rumen, is absorbed and taken up from hepatic portal blood for gluconeogenesis in the liver (Forbes \& Barrio, 1992). Feed intake might be regulated by the metabolism of propionate in the liver (Allen, 2000). Ruminal infusions of propionate decreased ME intake in lactating dairy cows relative to iso-osmotic infusions of acetate (Oba and Allen, 2003). In addition, reducing the $\mathrm{pH}$ of the rumen contents has a negative effect on cellulolytic bacteria (Sveinbjornsson et al., 2006) and inhibits rumen motility. So, it is uncertain whether the observed reduction in subsequent feed intake is due to physical or chemical stimuli (Forbes \& Barrio, 1992). Adding non-forage NDF to low-forage diets might reduce the negative effects of increased starch fermentation without increasing the filling effect of the feed to the same extent as forage NDF (Voelker \& Allen, 2003) because pectin and other fermentable fibre components are less likely to produce lactate.

An increased milk yield, due to partial replacement of barley with BP, may be a result of higher feed intake in ewes that could lead to an increased energy intake. In late pregnant sheep, energy and nitrogen demands of the rapidly-growing foetus are mostly met by the placental uptake of glucose and amino acids (Husted et al., 2008). Reduced intake and inadequate glucose synthesis during this period may predispose the animal to health disorders, limit milk production (Karcher et al., 2007) and reduce foetal growth (Nordby et al., 1987). Therefore, the energy density of the diet should be increased prior to lambing. Grain is often substituted for forage in diets in an effort to increase energy intake. However, starch in grain inhibits fibre digestion by depressing rumen $\mathrm{pH}$ or through competition with starch as a substrate (Van Soest, 1994). Beet pulp has a higher energy value than most forages (Firkins, 1997), increases fibre digestibility (Cunningham et al., 1993) and has a lower NFC content than most starchy cereal grains (NRC, 2001). The increased daily gain of lambs due to partial replacement of barley with BP may be a result of higher milk yield.

The results of the current study show that feeding Diet 2 in late pregnancy and early lactation decreased the concentration of triglycerides, HDL-cholesterol and VLDL-cholesterol. Feeding ewes with BP during late pregnancy and early lactation resulted in increased litter weight and growth of lambs. Thus, BP by virtue of its physical nature, digestible nutrient content and nutrient availability for optimum microbial degradation followed by uninterrupted absorption from the gastrointestinal tract, seems to be superior to high energy grains in practical sheep production. In late pregnant sheep, energy and nitrogen demands of the rapidly growing foetus are mostly met by the placental uptake of glucose and amino acids (Husted et al., 2008). Reduced intake and inadequate glucose synthesis during this period may predispose the animal to health disorders, limit milk production (Karcher et al., 2007) and reduce foetal growth (Nordby et al., 1987). Decreased ability to produce adequate glucose combined with the increased utilization of glucose by the placenta and foetus creates the risk of developing hypoglycaemia (Johnson, 2008). Van Knegsel et al. (2007) concluded that the glucogenic diet was effective in improving an energy balance and decreasing plasma $\beta$-hydroxybutyrate and liver triglyceride concentrations, suggesting a reduced risk of metabolic disorders in multiparous dairy cows fed a glucogenic diet. Also, infusions of $\beta$-hydroxybutyrate into sheep, at rates simulating maximum utilization, increased insulin concentrations and pancreatic insulin production, decreased plasma free and hepatic non-sterified fatty acid uptake and, consequently, decreased hepatic ketogenesis (Heitmann et al., 1987).

\section{Conclusions}

Feeding ewes with BP during late pregnancy and early lactation resulted in increased litter weight and growth of lambs and might reduce the negative effects of increased starch fermentation without increasing the filling effect of the feed and increase milk yield without detrimental effects on milk compositions. Thus, BP by virtue of its physical nature, digestible nutrient content and nutrient availability for optimum microbial degradation followed by uninterrupted absorption from the gastrointestinal tract seems, to be superior to high energy grains in practical sheep production, and late gestation and early lactation ewes can be supplemented with BP without detrimental effects on performance.

\section{Acknowledgements}

The authors gratefully appreciate the support received from the University of Agricultural and Natural Bioresources of Sari, Mazandaran, and Educational institute of Tajan, GhaemShahr, Mazandaran, Iran, for the completion of this study. 


\section{References}

Allen, M.S., 2000. Effects of diet on short-term regulation of feed intake by lactating dairy cattle. J. Dairy Sci. 83, 1598-1624.

AOAC, 2002. Official Methods of Analysis. Vol. I. $15^{\text {th }}$ ed. Association of Official Analytical Chemists. Arlington, V.A., USA.

Bell, A.W., 1995. Regulation of organic nutrient metabolism during transition from late pregnancy to early lactation. J. Anim. Sci. 73, 2804-2819.

Benson, M.E., Henry, M.J. \& Cardellino, R.A., 1999. Comparison of weigh-suckle-weigh and machine milking measuring ewe milk production. J. Anim. Sci. 77, 2330-2335.

Clark, P.W. \& Armentano, L.E., 1997. Influence of particle size on the effectiveness of beet pulp fiber. J. Dairy Sci. 80, 898-904.

Coffey, K.P., Paterson, J.A., Saul, C.S., Coffey, L.S., Turner, K.E. \& Bowman, J.G., 1989. The influence of pregnancy and source of supplemental protein on intake, digestive kinetics and amino acid absorption by ewes. J. Anim. Sci. 67, 1805-1814.

Conrad, H.R., 1966. Symposium on factors influencing the voluntary intake of herbage by ruminants: Physiological and physical factors limiting feed intake. J. Anim. Sci. 25, 227-235.

Cunningham, K.D., Cecava, M.J. \& Johnson, T.R., 1993. Nutrient digestion, nitrogen, and amino acid flows in lactating cows fed soybean hulls in place of forage or concentrate. J. Dairy Sci. 76, 3523-3535.

Dann, H.M., Carter, M.P., Cotanch, K.W., Ballard, C.S., Takano, T. \& Grant, R.J., 2007. Effect of partial replacement of forage neutral detergent fiber with by-product neutral detergent fiber in close-up diets on periparturient performance of dairy cows. J. Dairy Sci. 90, 1789-1801.

Drackley, J.K., Overton, T.R. \& Douglas, G.N., 2001. Adaptations of glucose and long-chain fatty acid metabolism in liver of dairy cows during the periparturient period. J. Dairy Sci. 84 (E. Suppl.), $100-112$.

Firkins, J.L., 1997. Effects of feeding nonforage fiber sources on site of fiber digestion. J. Dairy Sci. 80, 1426-1437.

Forbes, J.M. \& Barrio, J.P., 1992. Abdominal chemo- and mechanosensitivity in ruminants and its role in the control of food intake. Exper. Physiol. 77, 27-50.

Friedewald, W.T., Levy, R.I. \& Fredrickson, D.S., 1972. Estimation of the concentration of low-density lipoprotein cholesterol without the use of the preparative ultracentrifuge. Clin. Chem.18, 499-502.

Grummer, R.R., 1995. Impact of changes in organic nutrient metabolism on feeding the transition dairy cow. J. Anim. Sci. 73, 2820-2833.

Husted, S.M., Nielsen, M.O., Blache, D. \& Ingvartsen, K.L., 2008. Glucose homeostasis and metabolic adaptation in the pregnant and lactating sheep are affected by the level of nutrition previously provided during her late fetal life. Domes. Anim. Endocrinol. 34, 419-431.

Ingvartsen, K.L. \& Andersen, J.B., 2000. Integration of metabolism and intake regulation: A review focusing on periparturient animals. J. Dairy Sci. 83, 1573-1597.

Johnson, C.A., 2008. Glucose homeostasis during canine pregnancy: Insulin resistance, ketosis, and hypoglycemia. Theriogenology 70, 1418-1423.

Karcher, E.L., Pickett, M.M., Varga, G.A. \& Donkin, S.S., 2007. Effect of dietary carbohydrate and monensin on expression of gluconeogenic enzymes in liver of transition dairy cows. J. Anim. Sci. 85, 690-699.

Lanzas, C., Sniffen, C.J., Seo, S., Tedeschi, L.O. \& Fox, D.G., 2007. A revised CNCPS feed carbohydrate fractionation scheme for formulating rations for ruminants. Anim. Feed Sci. Technol. 136, 167-190.

Mansfield, H.R., Stern, M.D. \& Otterbye, D.E., 1994. Effects of beet pulp and animal by-products on milk yield and in vitro fermentation by rumen microorganisms. J. Dairy Sci. 77, 205-216.

Minor, D.J., Trower, S.L., Strang, B.D., Shaver, R.D. \& Grummer, R.R., 1998. Effects of nonfiber carbohydrate and niacin on periparturient metabolic status and lactation of dairy cows. J. Dairy Sci. $81,189-200$.

Murray, J.M.D., Longland, A., Hastie, P., Moore-Colyer, M. \& Dunnett, C., 2008. The nutritive value of sugar beet pulp-substituted lucerne for equids. Anim. Feed Sci. Technol. 140, 110-124.

Nafikov, R.A., Ametaj, B.N., Bobe, G., Koehler, K.J., Young, J.W. \& Beitz, D.C., 2006. Prevention of fatty liver in transition dairy cows by subcutaneous injections of glucagons. J. Dairy Sci. 89, 1533-1545. 
Nordby, D.J., Field, R.A., Riley, M.L. \& Kercher, C.J., 1987. Effects of maternal undernutrition during early pregnancy on growth, muscle cellularity, fiber type and carcass composition in lambs. J. Anim. Sci. $64,1419-1427$.

NRC, 2001. Nutrient Requirements of Dairy Cattle. 7th rev. ed. Natl. Acad. Sci., Washington, D.C., USA.

Oba, M. \& Allen, M.S., 2003. Intraruminal infusion of propionate alters feeding behavior and decreases energy intake of lactating dairy cows. J. Nutr. 133, 1094-1099.

O'Doherty, J.V. \& Crosby, T.F., 1996. The effects of feeding grass silage and molassed sugar-beet pulp either separately or as an ensiled mixture on the nutritional status and colostrum production of twinbearing pregnant ewes. Irish J. Agric. Food Res. 35, 99-112.

O'Doherty, J.V., Maher, P.F. \& Crosby, T.F., 1997. The performance of pregnant ewes and their progeny when offered grass silage, maize silage or a maize silage/ensiled super pressed pulp mixture during late pregnancy. Livest. Prod. Sci. 52, 11-19.

Overton, T.R. \& Waldron, M.R., 2004. Nutritional management of transition dairy cows: Strategies to optimize metabolic health. J. Dairy Sci. 87 (E. Suppl 1), 105-119.

SAS, 2002. User's Guide: Statistics. Version 8.2 Ed. SAS Inst. Inc., Cary, N.C., USA.

Smith, K.L., Waldron, M.R., Drackley, J.K., Socha, M.T. \& Overton, T.R., 2005. Performance of dairy cows as affected by prepartum dietary carbohydrate source and supplementation with chromium throughout the transition period. J. Dairy Sci. 88, 255-263.

Sveinbjornsson, J., Murphy, M. \& Uden, P., 2006. Effect of the proportions of neutral detergent fibre and starch, and their degradation rates, on in vitro ruminal fermentation. Anim. Feed Sci. Technol. 130, 172-190.

Swain, S.M. \& Armentano, L.E., 1994. Quantitative evaluation of fiber from nonforage sources used to replace alfalfa silage. J. Dairy Sci. 77, 2318-2331.

Van Knegsel, A.T.M., Van den Brand, H., Dijkstra, J., Van Straalen, W.M., Jorritsma, R., Tamminga, S. \& Kemp, B., 2007. Effect of glucogenic vs. lipogenic diets on energy balance, blood metabolites, and reproduction in primiparous and multiparous dairy cows in early lactation. J. Dairy Sci. 90, 3397-3409.

Van Soest, P.J., 1994. Nutritional Ecology of the Ruminant. 2nd ed. Cornell Univ. Press, Ithaca, N.Y., USA.

Van Soest, P.J., Robertson, J.B. \& Lewis, B.A., 1991. Methods for dietary fiber, neutral detergent fiber, and nonstarch polysaccharides in relation to animal nutrition. J. Dairy Sci. 74, 3583-3597.

Voelker, J.A. \& Allen, M.S., 2003. Pelleted beet pulp substituted for high-moisture corn: 1. Effects on feed intake, chewing behavior, and milk production of lactating dairy cows. J. Dairy Sci. 86, 3542-3552. 